\title{
Analisis Konektivitas Wilayah di Kota Denpasar
}

\author{
Aprilia Riszi Indah Dewi Shara
}

Masuk: 30032018 / Diterima: 28062018 / Dipublikasi: 30062018

(C) 2018 Fakultas Hukum dan IImu Sosial UNDIKSHA dan IGI

\begin{abstract}
Connectivity analysis is one of the most important things in a regional planning or development. A certain region can be developed properly if the connectivity system of the region is good too. The aim of this research is to identify regional hierarchy, service centers, and inter-regional interactions in each sub-district in Denpasar City. The method used in this research is quantitative method. Data analyzed by using index analysis of centrality, gravitation model, and konig-shimbel. The results showed that based on centrality index and gravity model, West Denpasar District has the highest value compared to the other three districts in Denpasar City. It shows that West Denpasar District is an area with hierarchy I (growth center) Denpasar City. Determination of hinterland-center of Denpasar is based on the availability of facilities in each sub-district.
\end{abstract}

Keywords: Connectivity; Hierarchy Areas

Abstrak Analisis konektivitas merupakan salah satu bagian terpenting dalam sebuah perencanaan atau pembangunan wilayah. Suatu wilayah dapat berkembang dengan baik apabila sistem konektivitas wilayahnya juga baik. Tujuan dari penelitian ini adalah mengidentifikasi hirarkiwilayah, pusat-pusatpelayanan, daninteraksiantarwilayah pada masing-masing kecamtan di Kota Denpasar. Metode yang dipergunakan dalam penelitian ini adalah metode kuantitatif. Data yang dikumpulkan dianalisis dengan menggunakan analisis indeks sentralitas, model gravitasi, dan konig-shimbel. Hasil penelitian menunjukkan berdasarkan indeks sentralitas dan model gravitasi, Kecamatan Denpasar Barat memiliki nilai tertinggi dibanding tiga kecamatan lain di Kota Denpasar. Hal ini menunjukkan bahwa Kecamatan Denpasar Barat merupakan wilayah dengan hirarki I (pusat pertumbuhan) Kota Denpasar. Penentuan pusat-hinterland Kota Denpasar didasari pada faktor ketersediaan saranaprasarana di masing-masing kecamatan.

Kata kunci: Konektivitas; Hirarki Wilayah

\section{Pendahuluan}

Menurut D.A. Tisnaadmidjaja (dalam Yusuf, 1997), yang dimaksud dengan ruang adalah "wujud fisik wilayah dalam dimensi geografis dan geometris yang merupakan wadah bagi manusia dalam melaksanakan kegiatan kehidupannya dalam suatu kualitas kehidupan yang layak". Tata ruang adalah w ujud struktur ruang dan pola ruang. Struktur ruang adalah susunan pusat-pusat permukiman dan sistem jaringan prasarana dan sarana yang berfungsi sebagai pendukung kegiatan sosial ekonomi masyarakat yang secara hierarki memiliki hubungan fungsional.

Aprilia Riszi Indah Dewi Shara

Fakultas Geografi Universitas Gadjah Mada

Yogyakarta

apriliariszi@gmail.com
Penataan ruang adalah suatu sistem proses perencanaan tata ruang, pemanfaatan tata ruang dan pengendalian pemanfaatan ruang. Hal tersebut merupakan ruang lingkup penataan ruang sebagai objek Hukum Administrasi Negara. Jadi, hukum penataan ruang menurut Undang-Undang Nomor 26 Tahun 2007 Tentang Penataan Ruang yaitu hukum yang berwujud struktur ruang (ialah susunan pusat-pusat pemukiman dan sistem jaringan prasarana dan sarana yang berfungsi sebagai pendukung kegiatan.

Analisis struktur tata ruang bertujuan untuk menemukenali permasalahan pengembangan wilayah/kawasan yang memiliki dimensi ruang (space). Analisis diarahkan sedemikian rupa sehingga mampu memberi gambaran secara 
menyeluruh tentang keadaan (termasuk jenjang peringkat/hierarki) pusat-pusat pelayanan yang ada pada kawasan terencanakan, jangkauan pelayanannya, serta hubungan/ interaksi antar pusatpusat pelayanan tersebut (Muta'ali, 2013).

Terdapat beberapa metode analisa yang dapat diterapkan sesuai dengan tujuannya, misalkan: untuk menemukenali daerah/lokasi strategis dapat didekati dengan analisa sistem hubungan (linkages analysis), untuk menentukan daerah/pusat permukiman yang kurang terlayani didekati dengan analisa pola permukiman (settlement analysis), untuk menemukenali daerah terisolasi dapat digunakan analisa aksesibilitas(accessibility analysis), dan/atau untuk menggabungkan/mensintesis hasil-hasil analisa tersebut dapat digunakan analisa planimetris. Selain itu, paper ini akan menguraikan identifikasi struktur ruang Kota Denpasar mengenai analisis kependudukan, analisis sistem pelayanan kegiatan, analisis sistem jaringan pergerakan dan analisis sistem jaringan utilitas. Selanjutnya membahas isu-isu strategis yang terkait struktur ruang.

\section{Metode}

Metode yang digunakan dalam penulisan paper ini yakni metode kuantitatif. Proses pencarian, pengumpulan, dananalisis data dilakukan dengan menggunakan studi kepustakaan dari berbagai sumber terpercaya, seperti Badan Pusat Statistik Kota Denpasar. Studi kepustakaan dilakukan dengan cara mengumpulkan data jumlah penduduk dan jarak antar kecamatan serta menganalisis berbagai referensi seperti artikel ilmiah, jurnal, buku, dan arsip akademis yang menjelaskan temuan, ide atau pendapat, dan konsep atau teori yang berhubungan dengan hirarki wilayah, pusat-pusat pelayanan, dan interaksi antar wilayah di Kota Denpasar.
Teknik analisis yang dapat digunakan untuk menentukan hirarki wilayah dan pusat pelayanan dalam jurnal ini adalah indeks sentralitas. Indeks sentralitas mempertimbangkan jumlah dan jenis fasilitas di suatu daerah dalam penentuan hirarki. Rumus indeks sentralitas adalah sebagai berikut:

$$
C=(x / X)
$$

Keterangan:

$C$ = Bobot atribut fungsi $x$

$X=$ Nilai Sentralitas Gabungan

$X=$ Jumlah total atribut dalam sistem

Teknik analisis yang digunakan untuk menghitung tingkat interaksi antar wilayah adalah model gravitasi. Rumus dari model gravitasi adalah sebagai berikut:

\section{$\mathrm{I}_{12}=\mathrm{G} \underline{\mathrm{M}}_{1} \underline{\mathrm{x} \mathrm{M}_{2}}$ \\ $J_{12}$}

Keterangan

$\mathrm{G} \quad=$ Konstanta Proporsional

$\mathrm{M}_{1} \quad=$ Massa wilayah 1

$\mathrm{M}_{2} \quad$ = Massa wilayah 2

$\mathrm{J}_{12}=$ Jarak antara wilayah 1 dan 2

Semakin tinggi nilai gravitasinya maka semakin erat hubungan antara dua daerah tersebut. Semakin tinggi jumlah model gravitasi maka wilayah tersebut mempunyai hirarki tinggi dan posisi strategis. Sementara itu, untuk mengetahui tingkat konektivtas wilayah digunakan teknik analisis Konig Shimbel dan Beta Index. Teknik Konig Shimbel mengidentifikasi keterhubungan antara satu wilayah dengan wilayah lainnya. Formula teknik analisis konektivitas menurut (Whynne \& Hammond, 1979) sebagai berikut:

- Konig (K) yaitu jumlah maksimum keterhubungan antara satu wilayah dengan wilayah yang lain. Sebagai contoh wilayah A memiliki nilai konig 
= 5 khususnya dengan wilayah $\mathrm{H}$, yaitu untuk menuju wilayah $\mathrm{H}$ dari wilayah $A$ harus menempuh lima jalur keterhubungan.

- Shimbel (S) yaitu jumlah keterhubungan suatu wilayah dengan wilayah-wilayah lain, dimna nilai Shimbel terendah adalah I, yang berarti wilayah I paling mudah dan cepat dijangkau oleh wilayah wilayah lainnya.

Tujuan praktis dalam paper ini adalah untuk mengetahuihirarkiwilayah, pusatpusatpelayanan, daninteraksiantarwilayah pada masing-masing kecamtan di Kota Denpasar sehingga dapat dilakukan upaya untuk menentukan kebijakan pengembangan wilayah lebih lanjut.

\section{Hasil dan Pembahasan Indeks Sentralitas}

Indek sentralitas menunjukan nilai strategis wilayah berdasarkan aspek lokasi geografis, dimana wilayah tersebut dicirikan dengan kemudahan akses dan banyaknya link dan simpul transportasi yang mengumpul pada wilayah tersebut. Wilayah yang memiliki nilai sentralitas tinggi pusat orientasi kegiatan dan menjadi wilayah tujuan (destination) (Muta'ali, 2015). Indeks Sentralitas juga bias diartikan sebagai indeks yang menunjukkan hirarki sebuah pusat dalam suatu wilayah. Ketersediaan dan jumlah fasilitas menjadi indicator dalam penentuan indeks sentralitas. Semakin lengkap ketersediaan dan jumlah fasilitas maka semakin tinggi hirarki suatu pusat. Fasilitas yang menjadi indicator adalah fasilitas ekonomi, kesehatan dan pendidikan. Fasilitas sosial (pendidikan dan kesehatan) disediakan sesuai dengan population threshold suatu daerah. Ketersediaan fasilitas ekonomi merupakan respon pasar terhadap perkembangan daerah tersebut.

Teori yang menjadidasar dalam penentuan hirarki wilayah dan pusat pelayanan adalah central place theory.Teori tersebut dicetuskan oleh Walter Christaller dari Jerman.Konsep pokok yang mendasari teori pusat pelayanan adalah daya layan dan jarak maksimum.

- Daya layan (Threshold Value) merupakan jumlah penduduk maksimal yang dibutuhkan untuk dapat menciptakan permintaan yang cukup atas barang atau pelayanan yang ditawarkan. Intinya adalah jumlah penduduk maksimum yang mampu ditampung sebuah fasilitas atau pelayanan.

- Jarak maksimum (Range of good) merupakan jarak tempuh maksimal untuk suatu jenis barang atau pelayanan tertentu. Semakin tinggi tingkat pelayanan maka semakin jauh jarak yang harus ditempuh. Jarak juga menentukan jenis, kualitas, dan harga barang yang ditawarkan.

Berdasarkan hal tersebut, untuk mengetahui indeks sentralitas Kota Denpasar, berikut disajikan data hasil perhitungan struktur ruang Kota Denpasar dengan menggunakan rumus indeks sentralitas yang terdapat pada Tabel 1 .

Tabel 1. Hasil Perhitungan Struktur Ruang Kota Denpasar

\begin{tabular}{clccc}
\hline No & Kecamatan & $\begin{array}{c}\text { Jumlah } \\
\text { Penduduk }\end{array}$ & $\begin{array}{c}\text { Indeks } \\
\text { Sentralitas }\end{array}$ & Keterangan \\
\hline 1 & Denpasar Selatan & 286060 & 339,98 & Hirarki II \\
2 & Denpasar Timur & 153480 & 279,23 & Hirarki III \\
3 & Denpasar Barat & 259790 & 431,29 & Hirarki I \\
4 & Denpasar Utara & 197970 & 349,94 & Hirarki II \\
\hline
\end{tabular}

Sumber: Hasil Analisis, 2018 
Dasar perhitungan pada Tabel 1 mengacu pada keberadaan sarana dan prasarana di masing-masing kecamatan di Kota Denpasar. Semakin banyak dan lengkapnya fasilitas di suatu wilayah, juga dapat menjadi tolak ukur perkembangan wilayah bersangkutan (diluar pertimbangan jumlah penduduk di masingmasing kecamatan).

Berdasarkan data pada Tabel 1, diketahui bahwa indeks sentralitas tertinggi terdapat di Kecamatan Denpasar Barat dengan indeks sentralitas 431,29, sedangkan yang terendah terdapat di Kecamatan Denpasar Timur dengan nilai indeks sentralitas 279,23. Hasil analisis menunjukkan 1 kecamatan memiliki fungsi sebagai hasil hirarki I, 2 kecamatan sebagai hirarki II, dan 1 kecamatan sebagai hirarki III. Berikut ini disajikan peta struktur ruang Kota Denpasar sebagai representasi dari perhitungan Tabel 1 yang terdapat dalam Gambar 1.

Mengacu pada hasil perhitungan pada Tabel 1 dan juga pada Gambar 1 Peta Struktur Ruang Kota Denpasar, penempatan Kecamatan Denpasar Barat sebagai hirarki I adalah tepat dan sesuai. Hal ini karena secara fungsional, Kecamatan Denpasar Barat memegang peranan penting, yakni sebagai pusat pemerintahan, pusat kegiatan ekonomi, pendidikan tinggi, dan juga pusat pelayanan kesehatan. Oleh karena faktorfaktor inilah, Kecamatan Denpasar Barat memiliki pegaruh yang paling kuat diantara kecamatan-kecamatan lain di Kota Denpasar. Keberadaan Pasar Badung sebagai sentral pasar tradisional di Kota Denpasar, RSUP Sanglah sebagai sentral rumah sakit di Kota Denpasar, Universitas Udayana sebagai Perguruan Tinggi Negeri yang paling populer, Lapangan Puputan sebagai salah satu RTH kota yang letaknya berdampingan dengan patung Catur Muka (titik nol Kota Denpasar), merupakan sebagian kecil dari contoh hirarki Kecamatan Denpasar Barat sebagai hirarki I. Belum lagi pusat pemerintahan kota juga berada di kecamatan ini, menambah kekuatan Kecamatan Denpasar Barat sebagai kecamatan dengan status hirarki I.

Sementara itu, Kecamatan Denpasar Selatan dan denpasar Utara masuk dalam kategori hirarki II, dan Kecamatan Denpasar Timur sebagai hirarki III. Hubungan antara hirarki I, II, dan III merupakan hubungan pusat dengan hinterland.Hubungan pusat wilayah dengan hinterland memiliki keterkaitan yang sangat erat. Keterkaitan ini diwujudkan dengan aktivitas pemasaran bahan baku atau komiditas. Pusat wilayah membutuhkan bahan baku dan tenaga kerja dari wilayah hinterland, sedangkan hinterland membutuhkan pusat wilayah untuk memasarkan komoditas dan memanfaatkan fasilitas pelayanan publik yang tersedia. Selain itu, pusat wilayah menyediakan lapangan pekerjaan bagi penduduk di wilayah hinterland. Hubungan yang seimbang akan berpengaruh positif terhadap pemerataan pembangunan wilayah dan kesejahtraan masyarakat.

\section{Analisis Gravitasi, Pusat wilayah dan Hinterland}

Berkaitan dengan koneksi antar wilayah, kekuatan keterkaitan wilayah satu dengan lainnya digunakan untuk menetapkan kekuatan tempat dari setiap pusat dan menemukan sistem pusat dan hinterland. Model gravitasi dapat digunakan untuk mengukur kekuatan interaksi antar kecamatan yang terdapat di Kota Denpasar. Data yang digunakan untuk mengukur kekuatan interaksi antar kecamatan adalah jumlah penduduk dan jarak. Data ini merupakan cerminan dari hambatan geografis pada suatu wilayah. Semakin tinggi nilai model gravitasi menunjukkan bahwa hubungan antar wilayah semakin erat. Hasil analisis terhadap model gravitasi Kota Denpasar terdapat pada Tabel 2. 


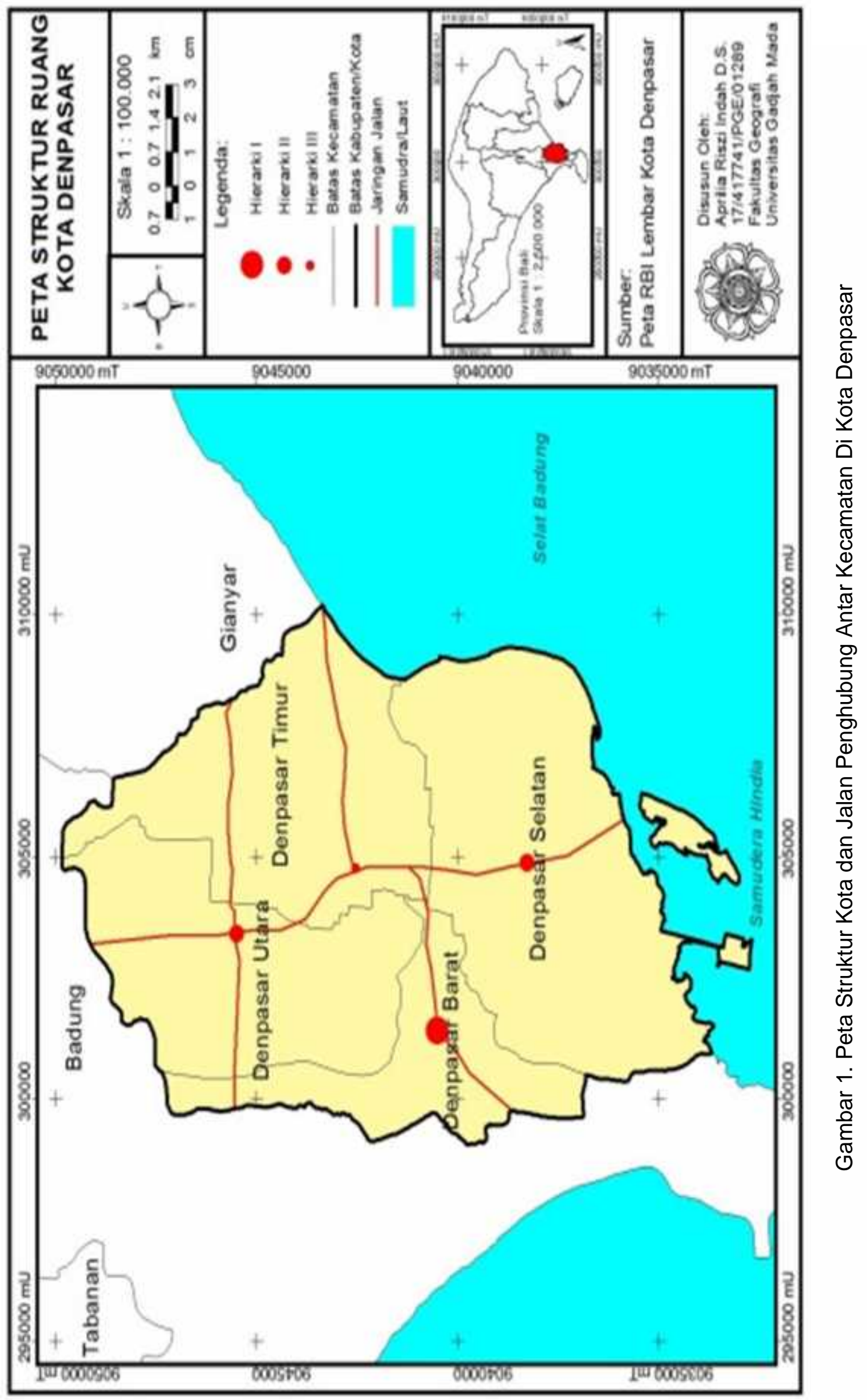


Tabel 2. Nilai Model Gravitasi Antar Kecamatan di Kota Denpasar

\begin{tabular}{clcrrr}
\hline No & Kecamatan & $\begin{array}{c}\text { Jumlah } \\
\text { Penduduk }\end{array}$ & $\begin{array}{c}\text { Rata-rata } \\
\text { Jarak ke } \\
\text { Kecamatan } \\
\text { Lain (Km) }\end{array}$ & $\begin{array}{c}\text { Total } \\
\text { Interaksi }\end{array}$ & $\begin{array}{c}\text { Kecamatan } \\
\text { dengan Interaksi } \\
\text { Paling Tinggi }\end{array}$ \\
\hline 1 & Denpasar Selatan & 286060 & 2 & 35847370517 & Denpasar Barat \\
2 & Denpasar Timur & 153480 & 2 & 28540373400 & Denpasar Selatan \\
3 & Denpasar Barat & 259790 & 2 & 41404680725 & Denpasar Selatan \\
4 & Denpasar Utara & 197970 & 2 & 26746131942 & Denpasar Barat \\
\hline
\end{tabular}

Sumber: Hasil Analisis, 2018

Berdasarkan Tabel 2 diketahui bahwa nilai interaksi tertinggi di Kota Denpasar terdapat di Kecamatan Denpasar Barat dengan nilai total interakasi mencapai 41.404.680.725. Berdasarkan letaknya, secara hirarki Kecamatan Denpasar Barat terhubung dengan seluruh kecamatan lain di Kota Denpasar, begitu pula sebaliknya. Oleh karena jumlah kecamatan hanya terdiri dari empat kecamatan, maka jarak antar satu kecamatan tidak saling berjauhan (rata-rata hanya berjarak $2 \mathrm{~km}$ ). Ditunjang dengan akses yang mudah, maka untuk melakukan mobile antar kecamatan juga tidak mengalami kendala berarti.

Namun demikian, alasan yang menjadikan Kecamatan Denpasar Barat sebagai kecamatan dengan interaksi tertinggi tidak lepas dari peranannya sebagai hirarki I. Ketersediaan fasilitas yang lengkap dan kebutuhan terkait kegiatan administrasi publik membuat penduduk banyak melakukan interaksi dengan kecamatan ini. Belum lagi supermarket dan pasar tradisional yang beraglomerasi di Kecamatan Denpasar Barat, menambah kekuatan interaksi penduduk wilayah lain ke kecamatan tersebut.
Sementara itu, nilai interaksi terendah terdapat di Kecamatan Denpasar Utara dengan angka 26.746.131.942. Hal yang menyebabkan Kecamatan Denpasar Utara memiliki nilai terendah bukanlah disebabkan oleh akses yang sulit, tetapi hal ini dapat disebabkan antara lain dari faktor jumlah penduduk. Kecamatan Denpasar Utara menempati posisi ke-3 dari empat kecamatan dalam jumlah kepadatan penduduk di Kota Denpasar. Tentu dengan jumlah penduduk yang lebih sedikit, maka proporsi interaksi juga kecil. Selain itu, fasilitas kesehatan di Kecamatan Denpasar Utara seperti rumah sakit, menempati jumlah paling sedikit dibanding kecamatan-kecamatan lain di Kota Denpasar. Faktor-faktor inilah yang berpeluang memberikan kontribusi rendah dalam hubungannya dengan nilai interaksi antar wilayah.

Sementara itu, selain menunjukkan nilai interaksi tertinggi di suatu wilayah, hasil penghitungan model gravitasi ini juga dapat menunjukkan wilayah mana yang memiliki kedudukan sebagai pusat dan wilayah mana yang memiliki kedudukan sebagai hinterland. Berikut adalah tabel yang menunjukkan kedudukan pusathinterland di Kota Denpasar yang disajikan dalam Tabel 3.

Tabel 3. Kedudukan Pusat-Hinterland Kota Denpasar

\begin{tabular}{ll}
\hline Pusat Wilayah & Hinterland \\
\hline Kecamatan & Kecamatan Denpasar Selatan, Kecamatan Denpasar Timur, \\
Denpasar Barat & Kecamatan Denpasar Utara
\end{tabular}

Sumber: Hasil Analisis, 2018 
Berdasarkan Tabel 3, yang menjadi penentu dalam hubungannya status sebagai pusat-hinterland adalah bukan disebabkan faktor jarak antara wilayah. Apabila berdasarkan jarak, seluruh kecamatan saling terhubung dan rata-rata hanya berjarak $2 \mathrm{~km}$ antar satu kecamatan dengan kecamatan lainnya. Penentuan pusat-hinterland untuk Kota Denpasar lebih didasari pada faktor ketersediaan sarana-prasarana di masingmasing kecamatan.

Berdasarkan aturan itu, maka dari sejumlah kecamatan yang ada di Kota Denpasar, Kecamatan Denpasar Baratlah yang memiliki fasilitas terlengkap dan dengan jumlah yang lebih banyak dibanding kecamatan-kecamatan lainnya. Selain itu, pusat-pusat kegiatan ekonomi, pendidikan, dan kesehatan juga terdapat di kecamatan ini. Sehingga, ketergantungan terhadap Kecamatan Denpasar Barat menjadi sangat tinggi, yang sekaligus berdampak pada tingginya nilai interaksi ke kecamatan tersebut. Hal ini juga sesuai dengan yang terdapat dalam Perda RTRW Kota Denpasar dalam penentuan pusat pelayanan kegiatan sosial-ekonomi skala wilayah yang disajikan dalam Tabel 4.

Tabel 4. Pusat Pelayanan Kegiatan Sosial-Ekonomi Skala Wilayah Berdasarkan Perda RTRW Kota Denpasar

\begin{tabular}{cll}
\hline No. & \multicolumn{1}{c}{ Pusat Pelayanan } & \multicolumn{1}{c}{ Wilayah } \\
\hline 1. & Pusat kegiatan pemerintahan & Kawasan sekitar Niti Mandala \\
2. & $\begin{array}{l}\text { Pusat kegiatan ekonomi, pendidikan } \\
\text { tinggi, dan pelayanan kesehatan } \\
\text { Kawasan sekitar Sanglah }\end{array}$ & \\
3. & $\begin{array}{l}\text { Pusat transportasi penumpang antar } \\
\text { wilayah Type B }\end{array}$ & Kawasan sekitar Terminal Ubung \\
4. & $\begin{array}{l}\text { Pusat transportasi laut antar wilayah } \\
\text { dan Internasional }\end{array}$ & Kawasan Pelabuhan Benoa \\
5. & Pusat perdagangan dan jasa & $\begin{array}{l}\text { Sepanjang Jalan Ngurah Rai, Gatot } \\
\text { Subroto, dan Jalan Mahendradata }\end{array}$ \\
6. & Pusat kawasan khusus pariwisata & Kawasan pariwisata Sanur \\
\hline
\end{tabular}

Mengacu pada Tabel 4, nampak bahwa pusat-pusat yang terdapat di nomor 1,2, dan 5 merupakan pusat-pusat yang berada di wilayah Kecamatan Denpasar Barat. Sementara pusat transportasi penumpang terdapat di Kecamatan Denpasar Utara. Pusat transportasi laut antar wilayah dan Internasional terdapat di Kecamatan Denpasar Selatan, begitupula dengan pusat kawasan khusus pariwisata juga terdapat di Kecamatan Denpasar Selatan.

Berdasarkan hal tersebut, wilayah dengan hirarki II, yakni Kecamatan Denpasar Selatan menjadi kecamatan yang paling berpeluang sebagai pusat pertumbuhan baru. Hal ini dikarenakan tidak hanya dikembangkan sebagai pusat transportasi laut antar wilayah dan Internasional ataupun pusat kawasan khusus pariwisata, tetapi Kecamatan Denpasar Selatan juga didukung dengan berbagai sarana-prasarana yang lengkap dan juga interaksi yang tertinggi (kedua setelah Denpasar Barat).

\section{Analisis Konektivitas}

Berdasarkan perhitungan Konig dan Shimbel, asumsi yang berlaku adalah semakin rendah nilai Konig-Shimbel, maka semakin baik (begitupula sebaliknya). Berdasarkan asumsi itu, sesuai dengan Tabel 5, maka diketahui yang menjadi daerah paling strategis adalah Kecamatan Denpasar Timur dengan perolehan skor Konig-Shimbel terendah, sedangkan Kecamatan Denpasar Barat menduduki skor tertinggi dan merupakan daerah yang nilai strategisnya terendah. 
Tabel 5. Hasil Perhitungan Konig dan Shimbel Kota Denpasar

\begin{tabular}{|c|c|c|c|c|c|c|}
\hline \multirow[t]{2}{*}{ Kecamatan } & \multicolumn{4}{|c|}{$\begin{array}{c}\text { Kode } \\
\text { Kecamatan }\end{array}$} & \multirow[t]{2}{*}{ KONIG } & \multirow[t]{2}{*}{ SHIMBEL } \\
\hline & A & $\mathrm{B}$ & C & D & & \\
\hline Denpasar Selatan & 0 & 1 & 2 & 2 & 2 & 5 \\
\hline Denpasar Timur & 1 & 0 & 2 & 1 & 2 & 4 \\
\hline Denpasar Barat & 2 & 2 & 0 & 2 & 2 & 6 \\
\hline Denpasar Utara & 2 & 1 & 2 & 0 & 3 & 5 \\
\hline
\end{tabular}

Sumber: Hasil Analisis, 2018

Namun demikian, jika mengacu pada penentuan hirarki sebelumnya, terdapat kondisi yang terbalik antara Kecamatan Denpasar Barat dengan Kecamatan Denpasar Timur. Pada penentuan hirarki, Kecamatan Denpasar Barat menempati hirarki I, maka semestinya memiliki nilai Konig-Shimbel yang paling rendah. Sementara itu, Kecamatan Denpasar Timur yang menempati hirarki III, semestinya memiliki skor nilai tertinggi.

Berkenaan dengan keunikan fenomena tersebut, maka dalam hal ini perlu ditekankan bahwa cakupan wilayah Kota Denpasar tidak seberapa luas (jika dibandingkan dengan Kabupaten/ Kota lain baik di Bali maupun luar Bali). Oleh karena itu, dalam urusan penentuan letak strategis, semua daerah saling terkait satu sama lain dan terkoneksi dengan sangat baik. Apabila dipergunakan skala jarak, maka rata-rata jarak antar wilayah satu dengan lainnya di Kota Denpasar hanya berjarak $2 \mathrm{~km}$ saja. Sehingga, kembali lagi pada penjelasan sebelumnya terkait alasan-alasan Kecamatan Denpasar Barat dapat menjadi pusat hirarki wilayah Denpasar, hal tersebut dipengaruhi oleh faktor ketersediaan prasarana-sarana yang sangat kompleks dan lengkap di kecamatan tersebut. Sementara itu, terkait skor Konig-Shimbel, dalam hubungannya dengan lokasi strategis Kota Denpasar, jarak bukanlah penentu dalam penghitungan lokasi strategis.

Fakta ini juga didukung oleh pembagian pusat-pusat BW dalam Perda RTRW Kota Denpasar. Berdasarkan sistem pusat pelayanan kota, terdapat lima pembagian, dimana pusat Kota Denpasar berada pada BWK Tengah. BWK tengah ini merupakan gabungan dari Kecamatan Denpasar Barat, Denpasar Utara, dan Kecamatan Denpasar Timur. Dominasi tertinggi dalam sistem dan fungsi perwilayahan pengembangan kota di BWK Tengah adalah di Kecamatan Denpasar Barat, disusul Kecamatan Denpasar Utara, dan terakhir Kecamatan Denpasar Timur (Peraturan Daerah Kota Denpasar Nomor 27 Tahun 2011 Tentang Rencana Tata Ruang Wilayah Kota Denpasar Tahun 2011 - 2031). Sehingga, berdasarkan pembagian ini, memang benar bahwa Kecamatan Denpasar Barat adalah kecamatan dengan hirarki I walau memiliki skor Konig-Shimbel tertinggi.

\section{Kesimpulan}

- Berdasarkan indeks sentralitas, dapat diklasifikasikan bahwa Kecamatan Denpasar Barat sebagai kecamatan dengan hirarki I, Kecamatan Denpasar Utara dan Kecamatan Denpasar Selatan sebagai hirarki II, dan Kecamatan Denpasar Timur sebagai hirarki III.

- Kecamatan Denpasar Barat memiliki pegaruh yang paling kuat diantara kecamatan-kecamatan lain di Kota Denpasar. Hal ini dipengaruhi oleh terpusatnya berbagai fasilitas dan pelayanan publik di Kecamatan Denpasar Barat.

- Berdasarkan nilai model gravitasi, nilai tertinggi secara berurutan diperoleh Kecamatan Denpasar Barat, Denpasar Selatan, Denpasar Timur, dan terakhir Denpasar Utara. 
- Hal yang menyebabkan Kecamatan Denpasar Utara memiliki nilai terendah bukanlah disebabkan oleh akses yang sulit, tetapi hal ini dapat disebabkan antara lain dari faktor jumlah penduduk. Tentu dengan jumlah penduduk yang lebih sedikit, maka proporsi interaksi juga kecil.

- Berdasarkan perhitungan KonigShimbel, terdapat kondisi yang terbalik antara Kecamatan Denpasar Barat dengan Kecamatan Denpasar Timur. Pada penentuan hirarki, Kecamatan Denpasar Barat menempati hirarki I, maka semestinya memiliki nilai KonigShimbel yang paling rendah. Sementara itu, Kecamatan Denpasar Timur yang menempati hirarki III, semestinya memiliki skor nilai tertinggi.

- Sesuai kasus Denpasar, yang menjadi penentu dalam hubungannya status sebagai pusathinterland adalah bukan disebabkan faktor jarak antara wilayah. Apabila berdasarkan jarak, seluruh kecamatan saling terhubung dan rata-rata hanya berjarak $2 \mathrm{~km}$ antar satu kecamatan dengan kecamatan lainnya. Penentuan pusat-hinterland untuk Kota Denpasar lebih didasari pada faktor ketersediaan saranaprasarana di masing-masing kecamatan

\section{Daftar Pustaka}

Muta'ali, L. (2013). Penataan Ruang Wilayah dan Kota (Tinjauan NormatifTeknis). Yogyakarta: Badan Penerbit Fakultas Geografi Universitas Gadjah Mada.

Muta'ali, L. (2015). Teknik Analisis Regional Untuk Perencanaan Wilayah, Tata Ruang dan Lingkungan. Yogyakarta: Badan Penerbit Fakultas Geografi Universitas Gadjah Mada.

Peraturan Daerah Kota Denpasar Nomor 27 Tahun 2011 Tentang Rencana Tata Ruang Wilayah Kota Denpasar Tahun 2011 - 2031.

Undang-Undang Nomor 26 Tahun 2007 Tentang Penataan Ruang.

Whynne, C., \& Hammond. (1979). Elements of Human Geography. London: George Allen \& Unwin.

Yusuf, A. W. (1997). Pranata Pembangunan. Bandung: Universitas Parahyangan. 